\author{
A.A. Sarsenbi \\ M. Auezov South Kazakhstan State University, Shymkent, Kazakhstan \\ (E-mail: abdisalam@mail.ru)
}

\title{
Unconditional basicity of eigenfunctions' system of Sturm-Liouville operator with an involutional perturbation
}

\begin{abstract}
In this paper the question on unconditional basicity of the system of eigenfunctions of the involutive perturbed Sturm-Liouville operator is investigated. The Green's function of the operator under consideration in the case of constant coefficients is constructed. The estimates of the Green's functions are obtained. The existence of the Green's function is shown in the case when the operator under consideration has a variable coefficient. The theorem on the equiconvergence of expansions with respect to the eigenfunctions of the indicated operators is proved with the help of the Green's function. The basicity of the eigenfunctions of the operator under consideration in the class $L_{2}(-1,1)$ is proved. It is established that the basis from the eigenfunctions of the involutive perturbed Sturm-Liouville operator is the unconditional basis.
\end{abstract}

Keywords: Involution, eigenfunction, eigenvalue, basis, Green's function.

\section{Introduction}

In the present paper we study a spectral problem of the form

$$
L u=-u^{\prime \prime}(x)+\alpha u^{\prime \prime}(-x)+q(x) u(x)=\lambda u(x), \quad-1<x<1, \quad u(-1)=0, \quad u(1)=0,
$$

where $q(x) \in C[-1,1]$ - is complex-valued function. The parameter $\alpha$ belongs to the interval $(-1,1)$. If $q(x) \equiv 0$, then the spectral problem (1)

$$
-u^{\prime \prime}(x)+\alpha u^{\prime \prime}(-x)=\lambda u(x), \quad u(-1)=0, u(1)=0
$$

is well-known [1], it has eigenvalues

$$
\lambda_{k 1}=(1-\alpha)\left(k+\frac{1}{2}\right)^{2} \pi^{2}, \quad \lambda_{k 2}=(1+\alpha) k^{2} \pi^{2}, \quad k=0, \pm 1, \pm 2, \ldots
$$

and eigenfunctions

$$
\left\{u_{k 1}(x)=\cos \left(l+\frac{1}{2}\right) \pi x, \quad k_{1}=0,1,2, \ldots ; \quad u_{k 2}(x)=\sin k \pi x, \quad k_{2}=1,2, \ldots\right\},
$$

which form a Riesz basis in $L_{2}(-1,1)$.

We show that the eigenfunctions' systems of the spectral problem (1) forms a basis in $L_{2}(-1,1)$.

Results on the spectral properties of one-dimensional differential operators with involution (we use the simplest one, that is, with reflection $v(x)=-x$ on $[-1,1])$ are actively applied in research of PDE. The recent papers by Aleorov, Kirane, and Malik [2], Kirane and Al-Sati [3] give natural examples. Various applications of differential operators with involutions can be found in [4].

Spectral theory of differential operators with involution forms a specific niche in the study of ODE. Eigenfunction expansions for the first-order differential operators with involution are considered in [5-7]. An example of second-order differential operators with involution are discussed in [8-10]. A specific example of a boundary-value problem for the second-order differential operator with involution that produces an infinite number of associated functions is given in [11, 12]. We also note valuable results on the Green's function for the boundary value problems related to functional-differential operators with involution (see Cabada and Tojo $[13,14]$ ) and new types of non-classical Sturm-Liouville problems (see Aidemir, Mukhtarov et al. [15, 16]). 
Green's function of the boundary value problem with involution

Along with the boundary value problem (2), we consider the non-homogeneous boundary value problem

$$
\begin{gathered}
-u^{\prime \prime}(x)+\alpha u^{\prime \prime}(-x)=\lambda u(x)+f(x), \quad-1<x<1 ; \\
u(-1)=0, \quad u(1)=0,
\end{gathered}
$$

where $-1<\alpha<1$, with the arbitrary continuous function $f(x)$. We note that equation in (5) contains an involution and corresponds to the homogeneous boundary value problem (2). It is clear that the functions

$$
\begin{gathered}
u_{1}(x)=\cos \left(\alpha_{0} \rho x\right), \quad u_{2}(x)=\sin \left(\alpha_{1} \rho x\right), \quad \rho=\sqrt{\lambda} ; \\
\alpha_{0}=\sqrt{\frac{1}{1-\alpha}}, \quad \alpha_{1}=\sqrt{\frac{1}{1+\alpha}},
\end{gathered}
$$

give linearly independent solutions to the homogeneous equation (2).

As usual, the Green's function $G(x, t, \lambda)$ of the boundary value problem $(2)$ is the kernel of the integral

$$
u(x)=\int_{-1}^{1} G(x, t, \lambda) f(t) d t
$$

that provides a solution to the problem (5).

Theorem 1. If $\lambda$ is not an eigenvalue of the problem (2), then the non-homogeneous boundary value problem (5) is solvable for any continuous function $f(x)$ and its solution can be represented in the form

$$
\begin{gathered}
u(x)=\frac{1}{2} \frac{\alpha_{0}}{\rho} \frac{\sin \alpha_{0} \rho}{\cos \alpha_{0} \rho} \cos \left(\alpha_{0} \rho x\right) \int_{-1}^{1} \cos \left(\alpha_{0} \rho t\right) f(t) d t- \\
-\frac{1}{2} \frac{\alpha_{1}}{\rho} \frac{\cos \alpha_{1} \rho}{\sin \alpha_{1} \rho} \sin \left(\alpha_{1} \rho x\right) \int_{-1}^{1} \sin \left(\alpha_{1} \rho t\right) f(t) d t+ \\
+\frac{1}{2 \rho}\left\{\int_{-1}^{-x}\left[\alpha_{0} \cos \left(\alpha_{0} \rho x\right) \sin \left(\alpha_{0} \rho t\right)-\alpha_{1} \sin \left(\alpha_{1} \rho x\right) \cos \left(\alpha_{1} \rho t\right)\right] f(t) d t-\right. \\
-\int_{-x}^{x}\left[\alpha_{0} \cos \left(\alpha_{0} \rho t\right) \sin \left(\alpha_{0} \rho x\right)-\alpha_{1} \sin \left(\alpha_{1} \rho t\right) \cos \left(\alpha_{1} \rho x\right)\right] f(t) d t- \\
\left.-\int_{x}^{1}\left[\alpha_{0} \cos \left(\alpha_{0} \rho x\right) \sin \left(\alpha_{0} \rho t\right)-\alpha_{1} \sin \left(\alpha_{1} \rho x\right) \cos \left(\alpha_{1} \rho t\right)\right] f(t) d t\right\} .
\end{gathered}
$$

Proof. Since the functions $\cos \left(\alpha_{0} \rho x\right), \sin \left(\alpha_{1} \rho x\right)$ are solutions to the homogeneous equation in (2), it is sufficient to show that the function

$$
\begin{gathered}
g_{0}(x) \equiv \frac{1}{2} \int_{-1}^{1} g(x, t, \lambda) f(t) d t= \\
=\frac{1}{2 \rho} \int_{-1}^{-x}\left[\alpha_{0} \cos \left(\alpha_{0} \rho x\right) \sin \left(\alpha_{0} \rho t\right)-\alpha_{1} \sin \left(\alpha_{1} \rho x\right) \cos \left(\alpha_{1} \rho t\right)\right] f(t) d t+ \\
+\frac{1}{2 \rho} \int_{-x}^{x}\left[-\alpha_{0} \cos \left(\alpha_{0} \rho t\right) \sin \left(\alpha_{0} \rho x\right)+\alpha_{1} \sin \left(\alpha_{1} \rho t\right) \cos \left(\alpha_{1} \rho x\right)\right] f(t) d t+
\end{gathered}
$$




$$
+\frac{1}{2 \rho} \int_{x}^{1}\left[-\alpha_{0} \cos \left(\alpha_{0} \rho x\right) \sin \left(\alpha_{0} \rho t\right)+\alpha_{1} \sin \left(\alpha_{1} \rho x\right) \cos \left(\alpha_{1} \rho t\right)\right] f(t) d t
$$

satisfies the equation in (1). The direct calculation of its first derivative

$$
\begin{aligned}
& g_{0}^{\prime}(x)=\frac{1}{2 \rho} \int_{-1}^{-x}\left[\alpha_{0}\left(\cos \left(\alpha_{0} \rho x\right)\right)^{\prime} \sin \left(\alpha_{0} \rho t\right)-\alpha_{1}\left(\sin \left(\alpha_{1} \rho x\right)\right)^{\prime} \cos \left(\alpha_{1} \rho t\right)\right] f(t) d t+ \\
& +\frac{1}{2 \rho} \int_{-x}^{x}\left[-\alpha_{0} \cos \left(\alpha_{0} \rho t\right)\left(\sin \left(\alpha_{0} \rho x\right)\right)^{\prime}+\alpha_{1} \sin \left(\alpha_{1} \rho t\right)\left(\cos \left(\alpha_{1} \rho x\right)\right)^{\prime}\right] f(t) d t+ \\
& +\frac{1}{2 \rho} \int_{x}^{1}\left[-\alpha_{0}\left(\cos \left(\alpha_{0} \rho x\right)\right)^{\prime} \sin \left(\alpha_{0} \rho t\right)+\alpha_{1}\left(\sin \left(\alpha_{1} \rho x\right)\right)^{\prime} \cos \left(\alpha_{1} \rho t\right)\right] f(t) d t
\end{aligned}
$$

and its second derivative

$$
\begin{gathered}
g^{\prime \prime}{ }_{0}(x)=-\frac{f(x)+\alpha f(-x)}{1-\alpha^{2}}+ \\
+\frac{1}{2 \rho} \int_{-1}^{-x}\left[\alpha_{0}\left(\cos \left(\alpha_{0} \rho x\right)\right)^{\prime \prime} \sin \left(\alpha_{0} \rho t\right)-\alpha_{1}\left(\sin \left(\alpha_{1} \rho x\right)\right)^{\prime \prime} \cos \left(\alpha_{1} \rho t\right)\right] f(t) d t+ \\
+\frac{1}{2 \rho} \int_{-x}^{x}\left[-\alpha_{0} \cos \left(\alpha_{0} \rho t\right)\left(\sin \left(\alpha_{0} \rho x\right)\right)^{\prime \prime}+\alpha_{1} \sin \left(\alpha_{1} \rho t\right)\left(\cos \left(\alpha_{1} \rho x\right)\right)^{\prime \prime}\right] f(t) d t+ \\
+\frac{1}{2 \rho} \int_{x}^{1}\left[-\alpha_{0}\left(\cos \left(\alpha_{0} \rho x\right)\right)^{\prime \prime} \sin \left(\alpha_{0} \rho t\right)+\alpha_{1}\left(\sin \left(\alpha_{1} \rho x\right)\right)^{\prime \prime} \cos \left(\alpha_{1} \rho t\right)\right] f(t) d t
\end{gathered}
$$

verify the equality in (5). The boundary conditions in (5) can be checked directly. The theorem is proved.

The theorem implies the following corollary.

Corollary 1. The Green's function of the boundary value problem (2) has the form

$$
\begin{gathered}
G(x, t, \lambda)=\frac{1}{2} \frac{\alpha_{0}}{2 \rho} \frac{\sin \alpha_{0} \rho}{\cos \alpha_{0} \rho}\left(\cos \alpha_{0} \rho x\right)\left(\cos \alpha_{0} \rho t\right)- \\
-\frac{1}{2} \frac{\alpha_{1}}{2 \rho} \frac{\cos \alpha_{1} \rho}{\sin \alpha_{1} \rho}\left(\sin \alpha_{1} \rho x\right)\left(\sin \alpha_{1} \rho t\right)+ \\
+\frac{1}{2 \rho}\left\{\begin{array}{l}
\alpha_{0}\left(\cos \alpha_{0} \rho x\right)\left(\sin \alpha_{0} \rho t\right)-\alpha_{1}\left(\sin \alpha_{1} \rho x\right)\left(\cos \alpha_{1} \rho t\right), t \leq-x ; \\
-\alpha_{0}\left(\cos \alpha_{0} \rho t\right)\left(\sin \alpha_{0} \rho x\right)+\alpha_{1}\left(\sin \alpha_{1} \rho t\right)\left(\cos \alpha_{1} \rho x\right),-x \leq t \leq x ; \\
-\alpha_{0}\left(\cos \alpha_{0} \rho x\right)\left(\sin \alpha_{0} \rho t\right)+\alpha_{1}\left(\sin \alpha_{1} \rho x\right)\left(\cos \alpha_{1} \rho t\right), t \geq x .
\end{array}\right.
\end{gathered}
$$

Using the explicit form of the Green function one can write down the expansion of an arbitrary function $f(x)$ from $L_{1}(-1,1)$ in the eigenfunctions of the spectral problem (2). The poles of the Green's function are the zeros of the functions $\cos \alpha_{0} \rho, \sin \alpha_{1} \rho$ :

$$
\begin{gathered}
\rho_{k 1}=\sqrt{\lambda_{k 1}}=\sqrt{(1-\alpha)}\left(k+\frac{1}{2}\right) \pi, \quad k=0,1,2, \ldots ; \\
\rho_{k 2}=\sqrt{\lambda_{k 2}}=\sqrt{(1+\alpha)} k \pi, \quad k=1,2, \ldots
\end{gathered}
$$

If the number $\sqrt{\frac{1-\alpha}{1+\alpha}}$ is not even, then all eigenvalues are single. On the complex $\rho$-plane we consider the circles $P_{k 1}, \quad k=0,1,2, \ldots ; P_{k 2}, k=1,2, \ldots$, with a common center at the origin and respective radius:

$$
P_{k 1}:|\rho|=\sqrt{1-\alpha}\left(k+\frac{1}{2}\right) \pi+\frac{1}{8} ; \quad P_{k 2}:|\rho|=\sqrt{1+\alpha} k \pi+\frac{1}{8} .
$$


These circles do not overlap and do not pass through the points $\rho_{k 1}$ and $\rho_{k 2}$. When $\lambda=\rho^{2}$ the circles $P_{k 1}$, $P_{k 2}$ turn into the circles

$$
\widetilde{P}_{k 1}:|\lambda|=\left(\sqrt{1-\alpha}\left(k+\frac{1}{2}\right) \pi+\frac{1}{8}\right)^{2} ; \quad \widetilde{P}_{k 2}:|\lambda|=\left(\sqrt{1+\alpha} k \pi+\frac{1}{8}\right)^{2}
$$

in the $\lambda$-plane, respectively. For any function $f(x) \in L_{1}(-1.1)$, the partial sums of the eigenfunctions's expansions for the spectral problem (2) can be written as [17]

$$
\sigma_{m}(f)=-\frac{1}{2 \pi i} \int_{\widetilde{P}_{m}}\left(\int_{-1}^{1} G(x, t, \lambda) f(t) d t\right) d \lambda=-\frac{1}{2 \pi i} \int_{P_{m}}\left(\int_{-1}^{1} G\left(x, t, \rho^{2}\right) f(t) d t\right) 2 \rho d \rho,
$$

where $P_{m}-$ is the circle with the radius $\rho_{m}=\max \left\{\rho_{k 1}+\frac{1}{8}, \rho_{k 2}+\frac{1}{8}\right\}$.

Further, changing the order of integration and using the residue theorem, we calculate the integral over the circle $P_{m}$

$$
\begin{gathered}
\sigma_{m}(f)=-\frac{1}{2 \pi i} \int_{-1}^{1}\left[\int_{P_{m}} G(x, t, \lambda) 2 \rho d \rho\right] f(t) d t= \\
=\int_{-1}^{1} \sum_{k=0}^{m} \cos \left(k+\frac{1}{2}\right) \pi x \cos \left(k+\frac{1}{2}\right) \pi t f(t) d t+ \\
+\int_{-1}^{1} \sum_{k=1}^{m} \sin k \pi x \sin k \pi t f(t) d t=\sum_{k=0}^{m}\left(\int_{-1}^{1} f(t) \cos \left(k+\frac{1}{2}\right) \pi t d t\right) \cos \left(k+\frac{1}{2}\right) \pi x+ \\
+\sum_{k=1}^{m}\left(\int_{-1}^{1} f(t) \sin k \pi t d t\right) \sin k \pi x .
\end{gathered}
$$

Thus, the partial sums of the eigenfunction expansions for the spectral problem (2) of the arbitrary integrable function $f(x)$ has the form

$$
\sigma_{m}(f)=\sum_{k=0}^{m} a_{k} \cos \left(k+\frac{1}{2}\right) \pi x+\sum_{k=1}^{m} b_{k} \sin k \pi x,
$$

where

$$
a_{k}=\int_{-1}^{1} f(t) \cos \left(k+\frac{1}{2}\right) \pi t d t, \quad b_{k}=\int_{-1}^{1} f(t) \sin k \pi t d t .
$$

Note that the system $\left\{\sin k \pi x, \cos \left(n+\frac{1}{2}\right) \pi x\right\}, k=1,2, \ldots, n=0,1,2 \ldots$, is a complete orthogonal system in $L_{2}(-1,1)$. Therefore, for all $f(x) \in L_{2}(-1,1)$ the partial sums $\sigma_{m}(f)$ of the form (6) converge to the function $f(x)$ with respect to the norm of the space $L_{2}(-1,1)$.

Further we need an estimate of the Green's function.

Let $\rho=\Re \rho+i \Im \rho$ and denote $\rho_{0}=\Im \rho$.

Let $O_{\varepsilon}\left(\rho_{k}\right)=\left\{\rho:\left|\rho-\rho_{k i}\right|<\varepsilon, i=1,2\right\}$ be a circle of sufficiently small radius $\varepsilon$.

Lemma 2. If $\rho \notin O_{\varepsilon}\left(\rho_{k}\right)$, then the Green's function $G(x, t, \lambda)$ of the boundary value problem (2) satisfies the following uniform estimate

$$
|G(x, t, \lambda)| \leq C|\rho|^{-1} r(x, t, \rho)
$$

with $-1 \leq x, t \leq 1$, where

$$
r(x, t, \rho)=\left(e^{-\alpha_{2}\left|\rho_{0}\right|(2-|x|-|t|)}+e^{-\alpha_{2}\left|\rho_{0}\right|(|| x|-| t||)}\right), \alpha_{2}=\min \left\{\alpha_{1}, \alpha_{0}\right\} .
$$


Proof. In the case when $t \geq x$ the Green's function can be rewritten in the form

$$
\begin{aligned}
G(x, t, \lambda) & =\frac{\alpha_{0}}{4 i \rho}\left\{-\frac{e^{-i \alpha_{0} \rho}}{e^{i \alpha_{0} \rho}+e^{-i \alpha_{0} \rho}}\left[e^{i \alpha_{0} \rho(x+t)}+e^{i \alpha_{0} \rho(t-x)}\right]+\right. \\
+ & \left.\frac{e^{i \alpha_{0} \rho}}{e^{i \alpha_{0} \rho}+e^{-i \alpha_{0} \rho}}\left[e^{i \alpha_{0} \rho(x-t)}+e^{i \alpha_{0} \rho(-x-t)}\right]\right\}+ \\
+ & \frac{\alpha_{1}}{4 i \rho}\left\{-\frac{e^{-i \alpha_{1} \rho}}{e^{i \alpha_{1} \rho}-e^{-i \alpha_{1} \rho}}\left[e^{i \alpha_{1} \rho(x+t)}-e^{i \alpha_{1} \rho(t-x)}\right]-\right. \\
& \left.-\frac{e^{i \alpha_{1} \rho}}{e^{i \alpha_{1} \rho}-e^{-i \alpha_{1} \rho}}\left[-e^{i \alpha_{1} \rho(x-t)}+e^{i \alpha_{1} \rho(-x-t)}\right]\right\}
\end{aligned}
$$

For sufficiently large $|\rho|$ the Green's function satisfies the following inequality

$$
\begin{aligned}
|G(x, t, \lambda)| & \leq \frac{\alpha_{0}}{4|\rho|}\left\{\frac{-e^{\alpha_{0} \rho_{0}}}{\mid e^{-\alpha_{0} \rho_{0}}-e^{\alpha_{0} \rho_{0} \mid}}\left[e^{-\alpha_{0} \rho_{0}(x+t)}+e^{-\alpha_{0} \rho_{0}(t-x)}\right]+\right. \\
& \left.+\frac{e^{-\alpha_{0} \rho_{0}}}{\mid e^{-\alpha_{0} \rho_{0}}-e^{\alpha_{0} \rho_{0} \mid}}\left[e^{-\alpha_{0} \rho_{0}(x-t)}+e^{-\alpha_{0} \rho_{0}(-x-t)}\right]\right\}+ \\
+ & \frac{\alpha_{1}}{4|\rho|}\left\{\frac{e^{\alpha_{1} \rho_{0}}}{\mid e^{-\alpha_{1} \rho_{0}}-e^{\alpha_{1} \rho_{0} \mid}}\left[e^{-\alpha_{1} \rho_{0}(x+t)}+e^{-\alpha_{1} \rho_{0}(t-x)}\right]+\right. \\
& \left.+\frac{e^{-\alpha_{1} \rho_{0}}}{\left|e^{-\alpha_{1} \rho_{0}}-e^{\alpha_{1} \rho_{0}}\right|}\left[e^{-\alpha_{1} \rho_{0}(x-t)}+e^{-\alpha_{1} \rho_{0}(-x-t)}\right]\right\} .
\end{aligned}
$$

Since $t>x>0$, one has $t+x>t-x, x-t>-x-t$. Therefore,

$$
|G(x, t, \lambda)| \leq \frac{\alpha_{0}}{4|\rho|}\left[e^{-\alpha_{0} \rho_{0}(2-x-t)}+e^{-\alpha_{0} \rho_{0}(t-x)}\right]+\frac{\alpha_{1}}{4|\rho|}\left[e^{-\alpha_{1} \rho_{0}(2-x-t)}+e^{-\alpha_{1} \rho_{0}(t-x)}\right]
$$

if $\rho_{0}>0$ and

$$
|G(x, t, \lambda)| \leq \frac{\alpha_{0}}{4|\rho|}\left[e^{\alpha_{0} \rho_{0}(2-x-t)}+e^{\alpha_{0} \rho_{0}(t-x)}\right]+\frac{\alpha_{1}}{4|\rho|}\left[e^{\alpha_{1} \rho_{0}(2-x-t)}+e^{\alpha_{1} \rho_{0}(t-x)}\right]
$$

if $\rho_{0}<0$.

Thus, for $t>x>0$ the Green's function satisfies the following estimate

$$
|G(x, t, \lambda)| \leq \frac{c_{1}}{|\rho|}\left(e^{-\alpha_{2}\left|\rho_{0}\right|(2-x-t)}+e^{-\alpha_{2}\left|\rho_{0}\right|(t-x)}\right), \quad \alpha_{2}=\min \left\{\alpha_{0}, \alpha_{1}\right\} .
$$

In the case of $-x<t<x$ the proof of lemma is similar to the previous case while the estimate of the Green's functions takes the form

$$
|G(x, t, \lambda)| \leq \frac{c_{2}}{|\rho|}\left[e^{-\alpha_{2}\left|\rho_{0}\right|(2-x-|t|)}+e^{-\alpha_{2}\left|\rho_{0}\right|(x-|t|)}\right] .
$$

In the case of $t<-x$ the estimate transforms into the following inequality

$$
|G(x, t, \lambda)| \leq \frac{c_{3}}{|\rho|}\left[e^{-\alpha_{2}\left|\rho_{0}\right|(2-|t|-x)}+e^{-\alpha_{2}\left|\rho_{0}\right|(|t|-x)}\right] .
$$

The last three inequalities provide the desired estimate

$$
|G(x, t, \lambda)| \leq \frac{C}{|\rho|}\left[e^{-\alpha_{2}\left|\rho_{0}\right|(2-|x|-|t|)}+e^{-\alpha_{2}\left|\rho_{0}\right||| x|-| t||}\right] .
$$

Lemma is proved. 
Theorems on the basis property of the eigenfunctions of the spectral problem (1)

We are interested in the possibility of expanding the arbitrary function $f(x) \in L_{2}(-1,1)$ in converging series related to the spectral problem (1) in the case when the complex-valued coefficient $q(x)$ is continuous over the interval $(-1,1)$.

We assume that there exists the Green's function $G_{q}(x, t, \lambda)$ of the boundary value problem (1). Let $G(x, t, \lambda)$ be the Green's function of the problem (2). Since almost everywhere on the interval $(-1,1)$ we have the relations:

$$
\begin{gathered}
-\frac{\partial^{2} G(x, t, \lambda)}{\partial x^{2}}+\alpha \frac{\partial^{2} G(-x, t, \lambda)}{\partial x^{2}}=\lambda G(x, t, \lambda) \\
-\frac{\partial^{2} G_{q}(x, t, \lambda)}{\partial x^{2}}+\alpha \frac{\partial^{2} G_{q}(-x, t, \lambda)}{\partial x^{2}}+q(x) G_{q}(x, t, \lambda)=\lambda G_{q}(x, t, \lambda)
\end{gathered}
$$

then

$$
\begin{gathered}
-\frac{\partial^{2}\left(G_{q}(x, t, \lambda)-G(x, t, \lambda)\right)}{\partial x^{2}}+\alpha \frac{\partial^{2}\left(G_{q}(x, t, \lambda)-G(x, t, \lambda)\right)_{x=-x}}{\partial x^{2}}- \\
-\lambda\left(G_{q}(x, t, \lambda)-G(x, t, \lambda)\right)=-q(x) G_{q}(x, t, \lambda) .
\end{gathered}
$$

The difference $G_{q}(x, t, \lambda)-G(x, t, \lambda)$ clearly satisfies the boundary condition (1). Therefore outside the poles of the function $G(x, t, \lambda)$ the Green's function $G_{q}(x, t, \lambda)$ satisfies the equality

$$
G_{q}(x, t, \lambda)-G(x, t, \lambda)=-\int_{-1}^{1} G(x, s, \lambda) q(s) G_{q}(s, t, \lambda) d s .
$$

Existence of the Green's function for the boundary value problem (1) is equivalent to the existence of a solution to the integral equation (7). We come to the following theorem.

Theorem 3. If the number $\sqrt{\frac{1-\alpha}{1+\alpha}}$ is not even, then for all sufficiently large $\rho, \rho \notin O_{\varepsilon}\left(\rho_{k}\right)$, then there exists a solution to the integral equation (7).

Proof. Let $G_{q 0}(x, t, \lambda) \equiv 0$ and

$$
G_{q, p+1}(x, t, \lambda)=G(x, t, \lambda)-\int_{-1}^{1} G(x, s, \lambda) q(s) G_{q}(s, t, \lambda) d s
$$

for all sufficiently large $|\rho|$.

For the Green's function $G(x, t, \lambda)$ of the problem (2) the estimate holds

$$
|G(x, t, \lambda)| \leq \frac{C}{|\rho|} r(x, t),
$$

where

$$
r(x, t)=e^{-\alpha_{2}\left|\rho_{0}\right||| x|-| t||}+e^{-\alpha_{2}\left|\rho_{0}\right|(2-|| x|-| t||)} .
$$

Relation (8) with $p=0$ yields the estimate

$$
\left|G_{q 1}(x, t, \lambda)\right|=|G(x, t, \lambda)| \leq \frac{C}{|\rho|} r(x, t) .
$$

For brevity, we introduce the notation

$$
\begin{aligned}
& \max \left|G_{q 1}(x, t, \lambda)\right||\rho| r^{-1}(x, t)=C_{0} \\
& \max \left|G_{q p+1}(x, t, \lambda)-G_{q p}(x, t, \lambda)\right||\rho| r^{-1}(x, t)=C_{p},
\end{aligned}
$$

where the maximum is taken with respect to $x \in[-1,1]$, for fixed $t$ and sufficiently large $|\rho|$ laying outside the poles of the function $G(x, t, \lambda)$. 
Let us show that

$$
C_{j} \leq \frac{C}{2^{j}}, \quad j=0,1,2, \ldots p .
$$

For $j=0$ estimate (10) follows from the first estimate (9). Let us assume that estimate (10) holds in the case $j=1,2, \ldots p$ and prove it for $j=p+1$. Taking into account the notation in (9), we get the inequality

$$
C_{p+1} \leq C \cdot C_{p}|\rho|^{-1} \max \int_{-1}^{1} r(x, s) r(s, t) r^{-1}(x, t)|q(s)| d s .
$$

Here we have the relation

$$
\begin{gathered}
r(x, s) \cdot r(s, t)=\left(e^{-\alpha_{0}\left|\rho_{0}\right|(2-|x|-|s|)}+e^{-\alpha_{0}\left|\rho_{0}\right||| x|-| s||}\right) \times \\
\times\left(e^{-\alpha_{0}\left|\rho_{0}\right|(2-|s|-|t|)}+e^{-\alpha_{0}\left|\rho_{0}\right||| s|-| t||}\right)= \\
=e^{-\alpha_{0}\left|\rho_{0}\right|(4-|x|-2|s|-|t|)}+e^{-\alpha_{0}\left|\rho_{0}\right|(2-|x|-|s|+|| s|-| t||)}+ \\
+e^{-\alpha_{0}\left|\rho_{0}\right|(2-|s|-|t|+|| x|-| s||)}+e^{-\alpha_{0}\left|\rho_{0}\right|(|| x|-| s||+|| s|-| t||)}
\end{gathered}
$$

The triangle inequality yields

$$
|| x|-| t|| \leq|| x|-| s||+|| s|-| t|| .
$$

The inequality

$$
|t|=|t|+|s|-|s| \geq|s|-|| t|-| s||
$$

implies

and the inequality

$$
|x|+|t| \geq|x|+|s|-|| t|-| s|| ;
$$

$$
|x| \geq|s|-\| x|-| s|| ;
$$

implies

$$
|x|+|t| \geq|t|+|s|-|| x|-| s|| .
$$

Therefore

$$
|| x|-| t||=|| x|-1+1-| t||<1-|x|+1-|t|<1-|x|+1-|t|+2-2|s|=4-|x|-|t|-2|s| .
$$

Hence

$$
r(x, s) \cdot r(s, t) \leq 2 r(x, t) .
$$

This inequality and the inequality (11) imply

$$
C_{p+1} \leq 2 C C_{p}|\rho|^{-1} \int_{-1}^{1}|q(s)| d s .
$$

For sufficiently large $|\rho|$, the inequality

$$
2 C|\rho|^{-1} \int_{-1}^{1}|q(s)| d s \leq \frac{1}{2}
$$

holds true.

Consequently, $C_{p+1} \leq \frac{C_{p}}{2}$ for any $p$ and hence the desired inequality (10) is verified.

It follows from the inequality (10) that the series

$$
\sum_{1}^{\infty}\left(G_{q, p+1}(x, t, \lambda)-G_{q p}(x, t, \lambda)\right)
$$


uniformly converges and hence its partial sum

$$
S_{n}(x)=G_{q, p+n}(x, t, \lambda)-G_{q 1}(x, t, \lambda)
$$

converges also.

Therefore the sequence $G_{q p}(x, t, \lambda)$ uniformly converges to its limit $G_{q}(x, t, \lambda)$ which satisfies the equation (2). The theorem is proved.

Let

$$
\sigma_{m}(f)=-\frac{1}{2 \pi i} \int_{-1}^{1}\left[\int_{P_{m}} G(x, t, \lambda) 2 \rho d \rho\right] f(t) d t
$$

be the partial sum of eigenfunction expansions related to the spectral problem $(2)$, where $f(x) \in L_{1}(-1,1)$. Denote by

$$
S_{m}(f)=-\frac{1}{2 \pi i} \int_{-1}^{1}\left[\int_{P_{m}} G_{q}(x, t, \lambda) 2 \rho d \rho\right] f(t) d t
$$

the partial sum of the eigenfunction expansion related to the spectral problem (1).

The sequence $S_{m}(f)$ is said to be equiconvergent with the sequence $\sigma_{m}(f)$ on an interval $-1 \leq x \leq 1$ if the difference $S_{m}-\sigma_{m}$ vanishes uniformly on the interval as $m \rightarrow \infty$.

Theorem 4. If the number $\sqrt{\frac{1-\alpha}{1+\alpha}}$ is not even, then for any function $f(x) \in L_{1}(-1,1)$ sequence $S_{m}(f)$ equiconverges with the sequence $\sigma_{m}(f)$ on the interval $-1 \leq x \leq 1$.

Proof. Consider the relation

$$
S_{m}(f)-\sigma_{m}(f)=-\frac{1}{2 \pi i} \int_{P_{m}}\left\{\int_{-1}^{1}\left[G_{q}(x, t, \lambda)-G(x, t, \lambda)\right] f(t) d t\right\} 2 \rho d \rho .
$$

It follows from the proof of Theorem 2 that

$$
\left|G_{q}(x, t, \lambda)\right| \leq \frac{2 C}{|\rho|} r(x, t) .
$$

This estimate and the equality (7) yield that

$$
\left|G_{q}(x, t, \lambda)-G(x, t, \lambda)\right| \leq 4^{2}|\rho|^{-2} r(x, t) \int_{-1}^{1}|q(s)| d s .
$$

Then the equality (12) gives the estimate

$$
\begin{gathered}
\left|S_{m}(f)-\sigma_{m}(f)\right| \leq \frac{2 C^{2}}{\pi} \int_{P_{m}}\left[\int_{-1}^{1} r(x, t)|f(t)| d t\right] \frac{2|\rho|}{|\rho|^{2}} d \rho \cdot \int_{-1}^{1}|q(s)| d s= \\
=\frac{4 C^{2}}{\pi} \int_{-1}^{1}|q(s)| d s \int_{P_{m}}\left[\int_{-1}^{1} r(x, t)|f(t)| d t\right]\left|\frac{d \rho}{\rho}\right| .
\end{gathered}
$$

If we use the notation

$$
C_{1}=\frac{4 C^{2}}{\pi} \int_{-1}^{1}|q(s)| d s
$$

then

$$
\left|S_{m}(f)-\sigma_{m}(f)\right| \leq C_{1} \int_{P_{m}}\left[\int_{-1}^{1} r(x, t)|f(t)| d t\right]\left|\frac{d \rho}{\rho}\right| .
$$


Let us divide the interval $(0,1)=\Delta_{1}+\Delta_{2}$ into two parts:

$$
\begin{gathered}
\Delta_{1}=(-1+\delta,-x-\delta) \cup(-x+\delta, x-\delta) \cup(x+\delta, 1-\delta) ; \\
\Delta_{2}=(-1,-1+\delta) \cup(-x-\delta,-x+\delta) \cup(x-\delta, x+\delta) \cup(1-\delta, 1)
\end{gathered}
$$

with a sufficiently small positive value of $\delta>0$. Then

$$
\begin{aligned}
\left|S_{m}(f)-\sigma_{m}(f)\right| & \leq C_{1} \int_{P_{m}} \int_{\Delta_{1}}\left(e^{-\alpha_{0}\left|\rho_{0}\right||| x|-| t||}+e^{-\alpha_{0}\left|\rho_{0}\right|(2-|| x|-| t||)}\right) \times \\
& \times|f(t)| d t\left|\frac{d \rho}{\rho}\right|+2 C_{1} \pi \int_{\Delta_{2}}|f(t)| d t .
\end{aligned}
$$

Since

$$
\int_{\Delta_{2}}|f(t)| d t=\int_{-1}^{-1+\delta}|f(t)| d t+\int_{-x-\delta}^{-x+\delta}|f(t)| d t+\int_{x-\delta}^{x+\delta}|f(t)| d t+\int_{1-\delta}^{1}|f(t)| d t,
$$

the choice of $\delta$ can make the second term in (13) less than $\frac{\varepsilon}{2}$.

If $\rho_{m}$ is the radius of the circle $P_{m}$, then the partition of the integral

$$
\begin{aligned}
& \int_{P_{m}} e^{-\alpha_{0}\left|\rho_{0}\right| \delta}\left|\frac{d \rho}{\rho}\right|=\int_{0}^{\frac{\pi}{4}} e^{-\alpha_{0} \delta \rho_{m}|\sin t|} d t+\int_{\frac{\pi}{4}}^{\frac{3 \pi}{4}} e^{-\alpha_{0} \delta \rho_{m}|\cos t|} d t+ \\
& +\int_{\frac{3 \pi}{4}}^{\frac{5 \pi}{4}} e^{-\alpha_{0} \delta \rho_{m}|\sin t|} d t+\int_{\frac{5 \pi}{4}}^{\frac{7 \pi}{4}} e^{-\alpha_{0} \delta \rho_{m}|\cos t|} d t+\int_{\frac{7 \pi}{4}}^{2 \pi} e^{-\alpha_{0} \delta \rho_{m}|\sin t|} d t
\end{aligned}
$$

provides the estimate

$$
\int_{P_{m}} e^{-\alpha_{0}\left|\rho_{0}\right| \delta}\left|\frac{d \rho}{\rho}\right|<\frac{C_{2}}{\left|\rho_{m}\right| \delta} .
$$

With sufficiently large value of $m$, the first term in (13) can be made less than $\frac{\varepsilon}{2}$.

The theorem is proved.

Remark. In $[18,19]$ the boundary value problem

$$
\begin{aligned}
& -u^{\prime \prime}(-x)+q(x) u(x)=\lambda u(x) ; \\
& u(-1)=u(1), u^{\prime}(-1)=u^{\prime}(1)
\end{aligned}
$$

is considered and the theorems similar to Theorems 2 and 3 are obtained.

Theorem 5. If the number $\sqrt{\frac{1-\alpha}{1+\alpha}}$ is not even, then the system of eigenfunctions of the spectral problem (1) forms the basis in $L_{2}(-1,1)$.

Proof. Let $\|\cdot\|_{2}$ denote the norm in $L_{2}(-1,1)$. Then for any function $f(x) \in L_{2}(-1,1)$, one obtains the estimate

$$
\left\|f-S_{m}\right\|_{2} \leq\left\|f-\sigma_{m}\right\|_{2}+\left\|\sigma_{m}-S_{m}\right\|_{2}<\varepsilon
$$

as the first term is less than $\frac{\varepsilon}{2}$ by virtue of the basis property of the eigenfunctions of the spectral problem (2), and the second term is less than $\frac{\varepsilon}{2}$ by virtue of the equiconvergence Theorem 3 . Theorem 4 is proved.

Unconditional basicity of the system of eigenfunctions of the spectral problem (1) does not follow from Theorem 4. By Theorem 4 the system of eigenfunctions of the spectral problem (1) forms a basis in $L_{2}(-1,1)$. It is well-known that for any basis $u_{k}$ in a Hilbert space $L_{2}(-1,1)$ the estimate

$$
\left\|u_{k}\right\|_{L_{2}(-1,1)}\left\|v_{k}\right\|_{L_{2}(-1,1)} \leq C
$$


holds [20], where $v_{k}$ is biortogonally adjoint system to $u_{k}$. Since the system of eigenfunctions of the spectral problem (1) forms a basis in $L_{2}(-1,1)$, then by Theorems of L.V. Kritskov and A.M. Sarsenbi [21] this basis is an unconditional basis in the same space. Thus, we get the following result

Theorem 6. Let all the conditions of Theorem 4 be satisfied. Then the system of eigenfunctions of the spectral problem (1) forms an unconditional basis in $L_{2}(-1,1)$.

This work was supported by the Committee of Science of the Ministry of Education and Science of the Republic Kazakhstan, project no. AP0531225.

\section{References}

1 Ashyralyev, A., \& Sarsenbi, A. (2017). Well-Posedness of a Parabolic Equation with Involution. Numerical Functional Analysis and Optimization, 1-10.

2 Aleroev, T.S., Kirane, M., \& Malik, S.A. (2013). Determination of a source term for a time fractional diffusion equation with an integral type over-determining condition. Electron. J. Differential Equations, 2013:270, 1-16.

3 Kirane, M., \& Al-Salti, N. (2016). Inverse problems for a nonlocal wave equation with an involution perturbation. J. Nonlinear Sci. Appl. 9, 1243-1251.

4 Figueroa, R., \& Pouso, R.L. (2011). Minimal and maximal solutions to second - order boundary value problems with state-dependent deviating arguments. Bull. Lond. Math. Soc., 43, 164-174.

5 Burlutskaya, M.S. (2014). Mixed problem for a first - order partial differential equation with involution and periodic boundary conditions. Comput. Math. Math. Phys. 54:1, 1-10.

6 Kopzhasarova, A.A., Lukashov, A.L., \& Sarsenbi, A.M. (2012). Spectral properties of non-self-adjoint perturbations for a spectral problem with involution. Abstr. Appl. Anal. 2012:ID590781, 1-5.

7 Sadybekov, M.A., \& Sarsenbi, A.M. (2012). Mixed problem for a differential equation with involution under boundary conditions of general form. In:First Intern. Conference on Analysis and Applied Mathematics (ICAAM 2012). Book Series: AIP Conference Proceedings 1470, 225-227.

8 Kopzhassarova, A.A., \& Sarsenbi, A.M. (2012). Basis Properties of Eigenfunctions of Second-Order Differential Operators with Involution. Abstract and Applied Analysis, Vol. 2012. Article ID 576843, 6, Doi: $10.1155 / 2012 / 576843$.

9 Sadybekov, M.A., \& Sarsenbi, A.M. (2012). Criterion for the basis property of the eigenfunction system of a multiple differentiation operator with an involution. Differential Equations, 48:8, 1112-1118.

10 Sarsenbi, A.M. (2010). Unconditional bases related to a nonclassicall second-order differential operator. Differential Equations 46:4, 509-514.

11 Kritskov, L.V., \& Sarsenbi, A.M. (2015). Spectral properties of a nonlocal problem for a second-order differential equation with an involution. Differential Equations, Vol. 51, No. 8, 984-990.

12 Kritskov, L.V., \& Sarsenbi, A.M. (2015). Basicity in $L_{p}$ of root functions for differential equations with involution. Electronic Journal of Differential Equations, No. 278, 1-9.

13 Cabada, A., \& Tojo, F.A.F. (2014). Solutions and Green's function of the first order linear equation with reflection and initial condition. Boundary Value Problems, 2014:99, 1-16.

14 Tojo, F.A.F. (2016). Computation of Green's functions through algebraic decomposition of operators. Boundary Value Problems, Vol. 2016:167, 1-15.

15 Aydemir, K., \& Mukhtarov, O.S. (2015). Second-order differential operators with interior singularity. Adv. Difference Equations. 2015:26, 1-10.

16 Mukhtarov, O.S., Olgar, H., \& Aydemir, K. (2015). Resolvent operator and specgrum of new type boundary value problems. Filomat 29:7, 1671-1680.

17 Coddington, E.A., \& Levinson, N. (1984). Theory of Ordinary Differential Equations. Krieger Publ. Co, 1984 .

18 Sarsenbi, A.M. (2017). Basicity Properties of Eigenfunctions of the Periodic Problem for Differential Operator $L u=-u^{\prime \prime}(-x)+q(x) u(x)$. AIP Conference Proceedings, Vol. 1880, 050015. 
19 Kritskov, L.V., \& Sarsenbi, A.M. (2016). Basis properties of eigenfunctions of the differential operator $-u^{\prime \prime}(-x)+q(x)$ with Cauchy data. AIP Conference Proceedings, Vol. 1789, 040002, doi: $10.1063 / 1.4968455$.

20 Mil'man, V.D. (1970). Geometric theory of Banach spaces. I. Theory of basic and minimal sets. Uspekhi mat. Nauk., Vol. 25, No. 3(153), 113-174.

21 Kritskov, L.V., \& Sarsenbi, A.M. (2017). Riesz basis property of system of root functions of second-order differential operator with involution. Differential Equations, Vol. 53, No. 1, 33-46.

\author{
Ә.Ә. Сәрсенбі
}

\title{
Инволютивті толқытылған Штурм-Лиувилл операторының меншікті функцияларының шартсыз базис болуы
}

\begin{abstract}
Мақалада шеттік шарттары Дирихле түрінде болатын инволюциясы бар Штурм-Лиувилл операторы меншікті функциялар жүйесінің базис болуы туралы мәселе зерттелген. Коэффициенттері тұрақты инволюциясы бар Штурм-Лиувилл операторының Грин функциясы құрылып, Грин функциясы үшін бағалаулар алынған. Коэффициенттері айнымалы инволюциясы бар Штурм-Лиувилл операторының да Грин функциясының бар болуы туралы теорема дәлелденген. Осы нәтижелердің көмегімен айтылып отырған екі оператордың меншікті функциялары бойынша жіктеулері бірқалыпты қабаттаса жинақталатындығы көрсетілген. Коэффициенті айнымалы инволюциясы бар Штурм-Лиувилл операторы меншікті функцияларының жүйесі $L_{2}(-1,1)$ кеңістігінде базис болатындығы көрсетілген. Және мұндай базистің шартсыз базис болатындығы дәлелденген.
\end{abstract}

Kiлm сөздер: инволюция, меншікті функциялар, меншікті мәндер, базис, Грин функциясы.

\author{
А.А. Сарсенби
}

\section{Безусловная базисность собственных функций инволютивно возмущенного оператора Штурма-Лиувилля}

\begin{abstract}
В статье исследован вопрос о безусловной базисности системы собственных функций инволютивно возмущенного оператора Штурма-Лиувилля. Построена функция Грина изучаемого оператора в случае постоянных коэффициентов. Получены оценки функций Грина. При наличии переменного коэффициента у изучаемого оператора показано существование функции Грина. Доказаны теорема о равносходимости разложений по собственным функциям указанных операторов с помощью функции Грина, а также базисность собственных функций в классе $L_{2}(-1,1)$ изучаемого оператора. Установлено, что базис из собственных функций инволютивно возмущенного оператора Штурма-Лиувилля является безусловным базисом.
\end{abstract}

Ключевые слова: инволюция, собственная функция, собственные значения, базис, функция Грина. 